Peter Mucka - George Juraj Stein - Peter Tobolka*

\title{
PASSSENGER RIDE COMFORT AND INTERNATIONAL ROUGHNESS INDEX SPECIFICATIONS IN THE SLOVAK REPUBLIC
}

New original results are presented on relation between passenger's whole-body vibration (WBV) and longitudinal road unevenness characterised by the International Roughness Index (IRI) in 100-m segments. Measurements were provided in nine different cars of six vehicle categories operated on about $1860 \mathrm{~km}$ of road network. Vibration total value based on the root mean square (RMS) of the frequency-weighted acceleration was used to quantify the ride comfort at seat surface and seat base (i.e. vehicle floor) in three orthogonal axes. The relations between passenger's acceleration response, comfort reaction levels according to the ISO 2631-1: 1997 and the IRI road unevenness classes, used by the Slovak Road Administration, were estimated. Results indicated higher WBV by $20 \%$ on the motorways than on the 1st and 2nd class roads in the same IRI road class. Using the same IRI road classes for motorways and the 1st and 2nd class roads seems not to be appropriate from the point of view of the whole-body vibrations.

Keywords: whole-body vibration, passenger car, road profile, international roughness index (IRI), ride comfort, highways and roads

\section{Introduction}

Longitudinal road unevenness is an important parameter of Pavement Management System [1] and in Slovak Republic is characterised by the IRI index. The IRI is the most commonly used worldwide index used for evaluating and managing road systems [2-3].

This study is aimed to identify the relation between the measured WBV of a passenger in a motor vehicle and IRI based on field measurements. Such results have not been previously summarized and discussed. Field measurements that reported this relation were rare in the past and most measurements were provided only in recent years [4-15]. Comprehensive overview of published relations between the WBV and IRI was provided in [16]. Several authors reported the frequency-weighted acceleration on the seat surface on test sections with a known IRI. They used a passenger car with a dummy [7], luxury SUV [9], luxury sedan [15], multifunction vehicle [4, 11], van [13], van and ambulance [5], bus [8] and truck with a trailer [5-6]. Vehicle speed ranged from 30 to $120 \mathrm{~km} / \mathrm{h}$. Most of published results were provided in the vertical direction only or in the three orthogonal axes at the seat surface.

Limitation of published results [4-15] is in limited length and number of processed sections; using only one vehicle speed; using only one test vehicle that does not represent a vehicle fleet; only one (vertical) direction for the WBV evaluation; absence of passenger cars among tested vehicles; long time between the IRI measurement and WBV measurement.

For the road network administration and maintenance, ride safety and vehicle R\&D purposes, is important to have an idea about induced WBV and comfort level for a particular IRI value, road category and vehicle speed.

The objectives of the work were as follows:

- Provide in-situ measurements of the WBV on the passenger's seat surface and seat base for different vehicle types, road categories and speeds;

- Synchronize measured longitudinal road unevenness data with the WBV measurements;

- Estimate the relation between the IRI, WBV and vehicle speed;

- Compare the IRI road classes used in the Slovak republic and induced WBV in a vehicle;

- Estimate the influence of road category, road unevenness class and vehicle speed on results

Presented results are novel in the following:

- IRI road classes were not compared to induced vibrations in a vehicle;

- Processing much wider length of road network and range of vehicle speeds;

- Considering nine different passenger cars of six vehicle categories;

- WBV results are evaluated as a function of the IRI road classes, road category and vehicle speed;

- Vehicle speed is considered as a parameter of a regression function;

- Considering six acceleration signals at the seat surface and seat base in three orthogonal axes;

- Short time elapsed between the road roughness and WBV measurements.

\footnotetext{
* Peter Mucka, George Juraj Stein, Peter Tobolka

Institute of Materials and Machine Mechanics, Slovak Academy of Sciences, Bratislava, Slovakia

E-mail: ummsmuc@savba.sk
} 
Table 1 Expected comfort reactions to vibration environments according to the ISO 2631-1: 1997 [28]

\begin{tabular}{cc}
\hline Vibration total value $a_{\mathrm{v}}\left(\mathrm{m} / \mathrm{s}^{2}\right)$ & Comfort level \\
\hline$<0.315$ & not uncomfortable \\
$0.315-0.63$ & a little uncomfortable \\
$0.5-1.0$ & fairly uncomfortable \\
$0.8-1.6$ & uncomfortable \\
$1.25-2.5$ & very uncomfortable \\
$>2$ & extremely uncomfortable \\
\hline
\end{tabular}

\section{International roughness index}

The IRI is essentially a computer-based virtual response-type system based on the response of a mathematical quarter-car vehicle model to a road profile. The IRI is based on simulation of the roughness response of a car travelling at $80 \mathrm{~km} / \mathrm{h}$ - it is the Reference Average Rectified Slope, which expresses a ratio of the accumulated suspension vertical motion of a vehicle, divided by the distance travelled during the test.

The IRI is a numeric that summarizes roughness qualities impacting vehicle response. The IRI is a dimensionless measure with units $(\mathrm{mm} / \mathrm{m}),(\mathrm{m} / \mathrm{km})$ or $(\mathrm{in} / \mathrm{mi})$. The algorithm was proposed by Sayers [17] and is also implemented in prEN 13036-5: 2017 [18] or ASTM E1926-08: 2015 [19]. The IRI is an indicator of longitudinal unevenness often used in Pavement Management Systems around the world [2-3] and in the Slovak Republic [20-26].

The IRI specifications around the world used one, two or more longitudinal profiles at specified distance from the right edge or the centre line of road lane [2]. In Slovakia, thirteen road profiles are processed to calculate the representative IRI value for the segment of road lane [2, 20,27].

\section{Whole-body vibration}

ISO 2631-1 [28-29] defines methods for measurement of periodic, random and transient whole-body vibrations. For the comfort of seated persons this clause applies to a frequency range 0.5 to $80 \mathrm{~Hz}$, which occurs in all six axes on the seat pan. Filter $W_{\mathrm{k}}$ specified in ISO 2631-1 is used for frequency weighting in the $z$-direction and all three orthogonal axes on the seat base. Filter $W_{\mathrm{d}}$ is used for the $x$ - and $y$-directions at the seat surface.

The WBV was quantified with the vibration total value $a_{\mathrm{v}}$ calculated from six measured signals on the seat surface and seat base in three orthogonal directions: $x$ - (longitudinal, i.e. foreand-aft), $y$ - (lateral), and $z$ - (vertical). The vibration total value or vector sum $a_{\mathrm{v}}$ of frequency-weighted RMS accelerations is calculated [28] by:

$$
a_{v}=\sqrt{k_{B x}^{2} a_{w B x}^{2}+k_{B y}^{2} a_{w B y}^{2}+k_{B z}^{2} a_{w B z}^{2}+k_{S x}^{2} a_{w S x}^{2}+k_{S y}^{2} a_{w S y}^{2}+k_{S z}^{2} a_{w S z}^{2}}
$$

Table $2 \operatorname{IRI}(\mathrm{mm} / \mathrm{m})$ road unevenness classification in a 20-m segment in Slovakia [20]

\begin{tabular}{cccc}
\hline Road class & $\begin{array}{c}\text { Motorways and } \\
\text { expressways }\end{array}$ & $\begin{array}{c}1^{\text {st }} \text { and } 2^{\text {nd }} \\
\text { class roads }\end{array}$ & $\begin{array}{c}3^{\text {rd }} \text { class roads and } \\
\text { local highways }\end{array}$ \\
\hline 1 (very good) & $<1.90$ & $<1.90$ & $<3.30$ \\
2 (good) & $1.91-3.30$ & $1.91-3.30$ & $3.31-5.00$ \\
3 (fair) & $3.31-5.00$ & $3.31-5.00$ & $5.01-8.00$ \\
4 (poor) & $5.01-8.00$ & $5.01-10.00$ & $8.01-14.00$ \\
5 (very poor) & $>8.00$ & $>10.00$ & $>14.00$ \\
\hline
\end{tabular}

where $a_{\mathrm{wSx}}, a_{\mathrm{wSy}}, a_{\mathrm{wSz}}\left(\mathrm{m} / \mathrm{s}^{2}\right)$ - the weighted RMS accelerations with respect to the orthogonal axes $(x-y$-, and $z$-) at the seat surface, respectively, $a_{\mathrm{wBx}}, a_{\mathrm{wBy}}, a_{\mathrm{wBz}}\left(\mathrm{m} / \mathrm{s}^{2}\right)$ - the weighted RMS accelerations at the seat base, $k_{\mathrm{Sx}}, k_{\mathrm{Sy}}, k_{\mathrm{Sz}}, k_{\mathrm{Bx}}, k_{\mathrm{By}}, k_{\mathrm{Bz}}$ - multiplying factors, where $k_{\mathrm{Sx}}=k_{\mathrm{Sy}}=k_{\mathrm{Sz}}=1, k_{\mathrm{Bx}}=k_{\mathrm{By}}=0.25$, and $k_{\mathrm{Bz}}=0.4$ for comfort evaluation.

Table 1 presents the scale of the vibration total value $a_{\mathrm{v}}$ acting on a seated human body according to the ISO 2631-1 [28]. The comfort levels in Table 1 correspond to "likely reactions" of passengers in a public transport.

The WBV measurements were provided in a moving vehicle with a compact vibration measurement system [30-31] equipped by the two MEMS three-axial accelerometers CXL04LP3 [32] at passenger's seat surface and seat base (i.e., floor), a GPS sensor - GPS Garmin 18x - 5 Hz [33-34], data acquisition unit DT 9816 [35], acquisition software and a laptop. Figure 1 shows a scheme of an in-situ WBV measurement and evaluation in a test vehicle.

\section{Road profile data}

Longitudinal road profiles were measured in Slovakia in 2017 by Profilograph GE measuring device. Profile measurements were provided by Road databank of Slovak Road Administration. Profilograph GE records of sixteen parallel profiles (Figure 1). Laser sensor No. 16 typically records the vertical displacement of longitudinal profile at the right edge line of the road lane. Laser sensors No. 2-14 are used that record vertical displacement of the thirteen longitudinal profiles in the transverse distance from 0.3 to $2.4 \mathrm{~m}$ from the right edge of the road lane [2, 20,27]. Sample interval, which is a longitudinal distance between data capture points, was $52.91 \mathrm{~mm}$.

Technical specifications of inertial profilograph are presented in [20]. The Profilograph GE consists of: host vehicle - VW multivan, measuring beam equipped by 16 height sensors (singlespot laser sensors LMI SELCOM 5000), odometer, GPS sensors, operating unit, computer, and software Profilograph for Windows ${ }^{\circledR}$. The Profilograph GE meets the requirements of an ASTM E950 Class 1 [36] profiling device.

Longitudinal road unevenness evaluation in Slovakia (Table 2) is based on thirteen parallel profiles [20] measured by the Profilograph GE. Maximum IRI of those profiles is used as a representative value in a segment of specified length $(20 \mathrm{~m}$ or $100 \mathrm{~m})$. 

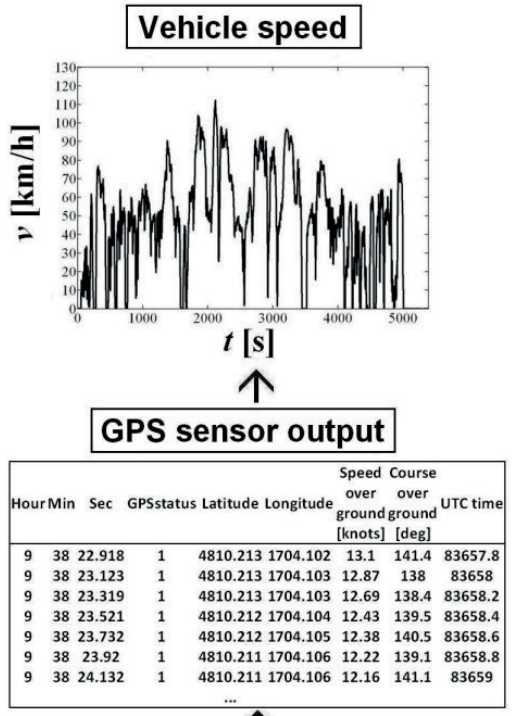
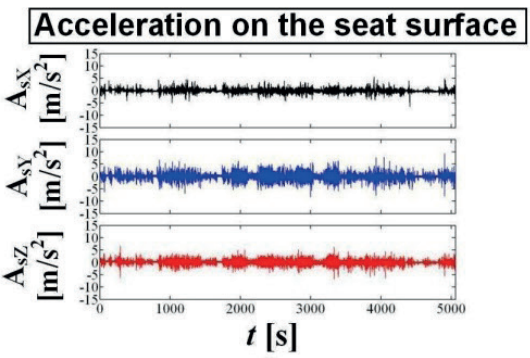

$\uparrow$

Acc. sensor output

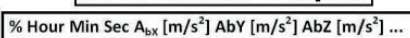
$\%$ AsX $\left[\mathrm{m} / \mathrm{s}^{2}\right]$ AsY $\left[\mathrm{m} / \mathrm{s}^{2}\right]$ AsZ[m/ $\left./ \mathrm{s}^{2}\right]$

$9383.336-0.088-0.140-0.0041 .1034 .0611 .075$ $9383.341-0.011-0.164-0.0521 .1454 .1511 .045$ $9383.346-0.053-0.188-0.1791 .1574 .1451 .081$ $9383.351-0.082-0.164-0.2271 .0614 .1331 .081$ 38 $3.3360 .018-0.212-0.1971 .0854 .1451 .124$ 9 $383.366-0.047-0.200-0.04011841 .0311 .063$

$9383.371-0.076-0.2240 .0381 .1334 .0851 .111$

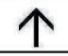

$\uparrow$

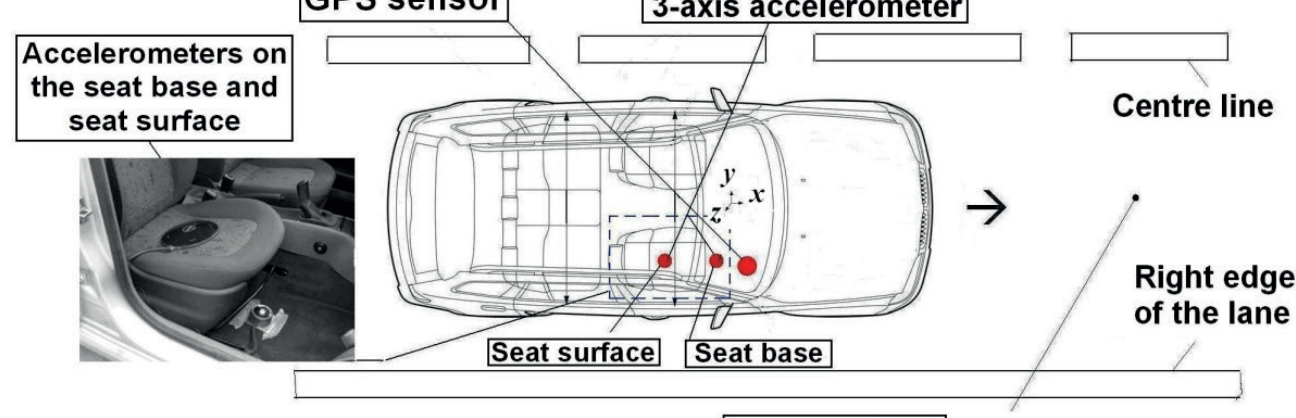

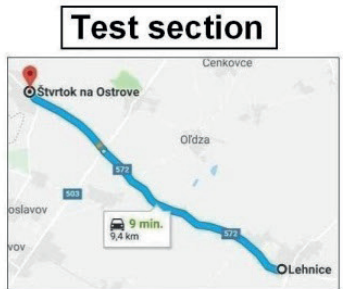

C 2017 Google

GPS output of Profilograph measurement

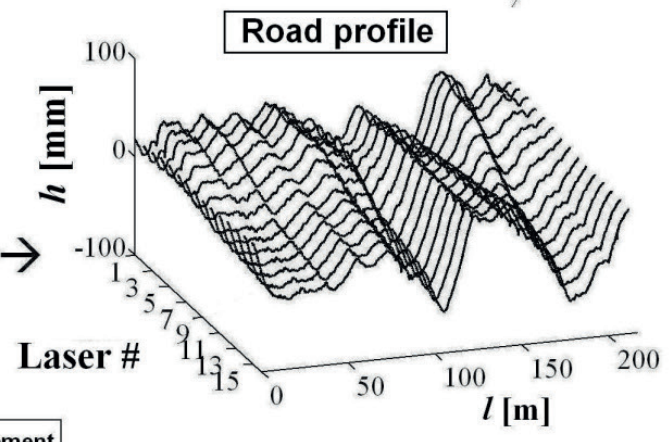

Distance [m], Time [s], Latitude [dd.dddd], Longitude [dd.dddd], Height [m],

Height of geoid [m], DOP, Satellites, Fixtype, GPStime, Method, Vcar [rad] $20.00,11.25,48.181292262,17.056753854,214.14,42.77,1.30,8,2,70717.00,0,-1.01$ $40.00,12.71,48.181390316,17.056528219,213.96,42.77,1.30,8,2,70719.00,0,-0.98$ $60.00,14.18,48.181491110,17.056306159,213.75,42.77,1.30,8,2,70720.00,0,-0.97$ 80.00, 15.67, 48.181593134, 17.056084568, 213.09, 42.77, 1.30, 8, 2, 70722.00, 0, -0.97 $100.00,17.16,48.181695620,17.055863710,212.70,42.77,1.30,8,2,70723.00,0,-0.96$ $120.00,18.64,48.181798632,17.055644193,211.88,42.77,1.30,8,2,70725.00,0,-0.96$ $140.00,20.11,48.181900966,17.055423429,211.51,42.77,1.30,8,2,70726.00,0,-0.97$ 18.00, 21.57, $8.18202781,17.055201212,210.84,42.77,1.30,8,2,70728.00,0,0.97$ $200.00,24.44,48.182223326,17.054781092,210.38,42.77,1.30,8,2,70730.00,0,-0.85$

IRI output of Profilograph measurement

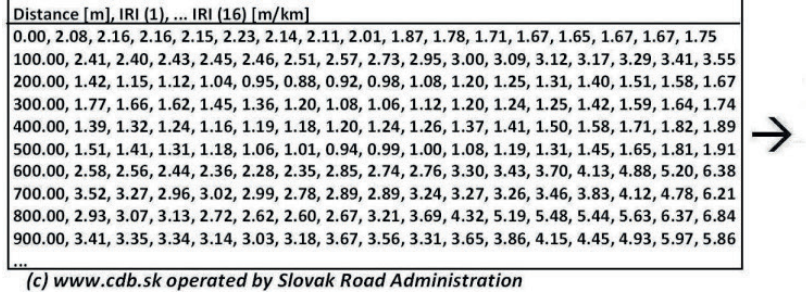

Figure 1 Scheme of the whole-body vibration measurement in a test vehicle 
Table 3 Fitting parameters of function IRI $=f(a, v)$ [Equation (2)] as a function of road category

\begin{tabular}{|c|c|c|c|c|c|c|c|c|}
\hline Road category & $N$ & Length (km) & $b_{1}$ & $b_{2}$ & $b_{3}$ & RMSE & $R$ & $R^{2}$ \\
\hline Motorways & 3808 & 380.8 & 1.859 & -0.011 & 1.251 & 0.554 & 0.374 & 0.140 \\
\hline $1^{\text {st }}$ class roads & 4684 & 468.4 & 5.145 & -0.05 & 3.058 & 1.1039 & 0.653 & 0.427 \\
\hline $1^{\text {st }}$ and $2^{\text {nd }}$ class roads & 10146 & 1014.6 & 5.696 & -0.059 & 3.866 & 1.4027 & 0.645 & 0.416 \\
\hline
\end{tabular}

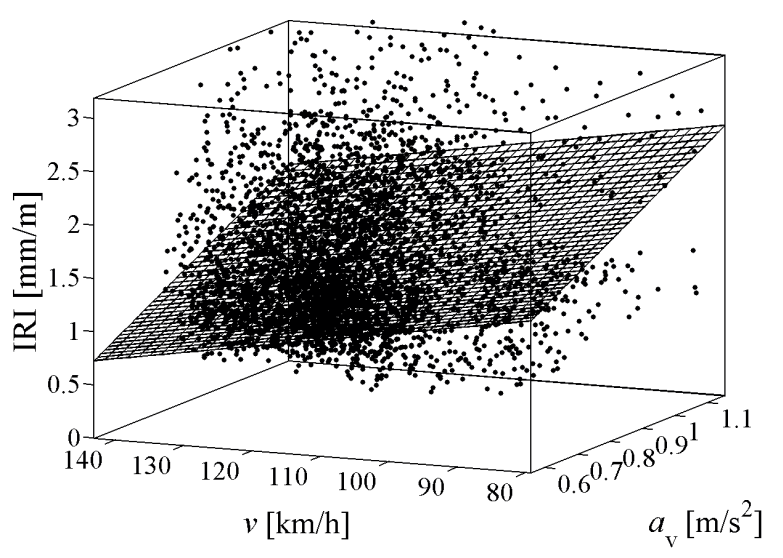

(a)

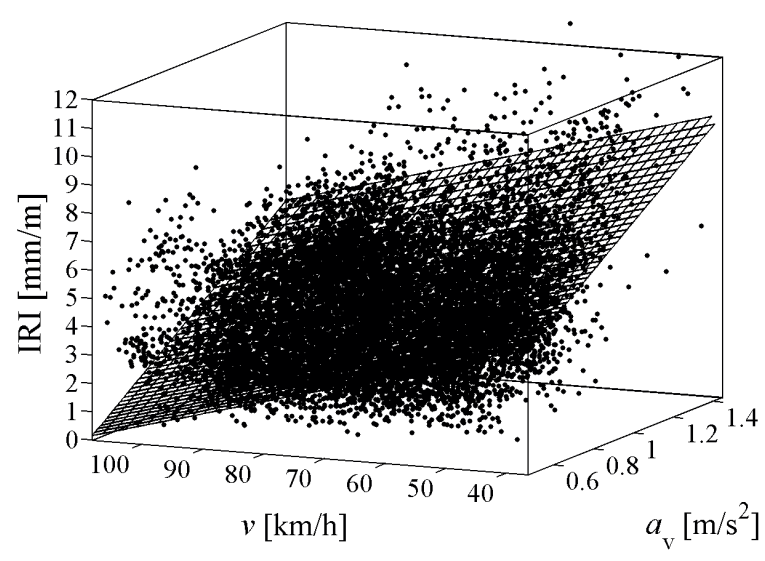

(b)

Figure 2 Relation IRI $=f\left(a_{v} v\right)$ for all the test vehicles as a function of road category: a) motorways, (b) the $1^{\text {st }}$ and $2^{\text {nd }}$ class roads

\section{Test vehicles survey}

Nine test vehicles that are representatives of the best-selling cars in Slovakia in recent years and typical representatives of current vehicle fleet were used: Skoda Fabia II, Skoda Octavia, Skoda Rapid, Skoda Citigo, Skoda Yeti, Skoda Superb, Hyundai i40 combi, Volkswagen Golf Plus, and Ford Transit.

Six different vehicle categories were considered: small and large family car, limousine, city car, sport utility vehicle (SUV) and a cargo van. Vehicles were produced between years 2005 and 2017 and actual vehicle millage was from $1600 \mathrm{~km}$ to $120000 \mathrm{~km}$. An average time elapsed between the profile measurement and WBV measurement was about 4 months. All measurements were conducted on the same passenger with the weight of $85 \mathrm{~kg}$. Two different test drivers of weight $75 \mathrm{~kg}$ and $90 \mathrm{~kg}$ conducted the tests.

\section{Whole-body vibration and IRI road classes}

The IRI data were evaluated by Profilograph GE [20] in sixteen parallel longitudinal profiles and sampled at report interval of $100 \mathrm{~m}$ and stored with corresponding geographic coordinates - latitude and longitude data (Figure 1).

The GPS coordinates of the WBV response in a vehicle were synchronized with the GPS data of profile measurements. Processed data should fulfil following conditions for partial processed interval of $100 \mathrm{~m}$ :

- Coefficient of variation of a vehicle speed is lower than $10 \%$;

- Difference in identified start points and final points of a 100-m segment between the WBV and profile measurements is lower than $5 \%$ of the segment length (i.e., $5 \mathrm{~m}$ ).
The total length of measured sections was about 1860 $\mathrm{km}$ and after elimination of section that does not fulfil the abovementioned conditions $\sim 1400 \mathrm{~km}$ was used for analysis.

Based on processing of measured data, a three-parameter relation between the IRI, $a_{\mathrm{v}}$ and $v$ was identified as the most appropriate, which is expressed as follows:

$\mathrm{IRI}=b_{1} a_{\mathrm{v}}+b_{2} v+b_{3}$,

where $b_{1}, b_{2}, b_{3}$ are constants of a fitting function. Table 3 shows identified fitting function parameters (Equation 2) for the processed road categories. The lower correlation was expected between IRI and $a_{v}$ in Table 3. Representative value of the IRI in each 100-m segment is based on the maximum IRI value of thirteen measured profiles. This profile may be different from current wheel paths of a test vehicle. Measurements were provided in nine different test vehicles of different vehicle categories and different vibrations response characteristics. Figure 2 shows measured data of relation of IRI and $a_{\mathrm{v}}$ and $v$, fitted by the regression function (Equation 2) for all the tested vehicles and the two road categories: motorways (Figure 2(a)) and the and $2^{\text {nd }}$ class roads (Figure 2(b)). Parameters of fitting function used in Figure 2 are presented in Table 3. Equation 2 may serve for a basic estimation of IRI values as a function of a passenger's vibrations and speed.

Table 4 shows statistics (mean, standard deviation, percentiles $\mathrm{P} 10, \mathrm{P} 25, \mathrm{P} 50, \mathrm{P} 75$, and $\mathrm{P} 90$ ) of total acceleration $a_{v}$ as a function of IRI road classes for all the nine tested vehicles and all tested sections. Processed test sections on motorways covered only first three IRI road classes used in the Slovak Republic.

Median $a_{\mathrm{v}}$ value (P50) exceeds the lower bound of expected "uncomfortable" human reaction $\left(a_{\mathrm{v}}=0.8 \mathrm{~m} / \mathrm{s}^{2}\right.$, Table 1) for all three IRI road classes (\#1 - \#3) and motorways and three IRI road 
Table 4 Vibration total value statistics as a function of IRI road classes and road category

\begin{tabular}{|c|c|c|c|c|c|c|c|c|c|c|c|c|c|c|c|}
\hline \multirow[t]{2}{*}{$N$} & \multirow{2}{*}{$\begin{array}{l}\text { Length } \\
(\mathrm{km})\end{array}$} & \multirow{2}{*}{$\begin{array}{c}\text { IRI } \\
\text { road } \\
\text { class }\end{array}$} & \multicolumn{2}{|c|}{$\begin{array}{c}v \\
(\mathrm{~km} / \mathrm{h})\end{array}$} & \multicolumn{4}{|c|}{ IRI $(\mathrm{mm} / \mathrm{m})$} & \multicolumn{7}{|c|}{$\begin{array}{l}\text { Vibration total value } \\
\qquad a_{\mathrm{v}}\left(\mathrm{m} / \mathrm{s}^{2}\right)\end{array}$} \\
\hline & & & mean & std & $\min$ & $\max$ & mean & std & mean & std & P10 & P25 & P50 & P75 & P90 \\
\hline \multicolumn{16}{|c|}{ Motorways } \\
\hline 2940 & 294 & 1 & 118.3 & 14.4 & 0 & 1.9 & 1.2 & 0.32 & 0.804 & 0.120 & 0.648 & 0.725 & 0.803 & 0.880 & 0.954 \\
\hline 837 & 83.7 & 2 & 118.5 & 14.5 & 1.9 & 3.3 & 2.3 & 0.34 & 0.883 & 0.147 & 0.683 & 0.787 & 0.883 & 0.985 & 1.069 \\
\hline 31 & 3.1 & 3 & 111.5 & 14 & 3.3 & 5 & 3.7 & 0.38 & 0.940 & 0.255 & 0.596 & 0.739 & 0.972 & 1.111 & 1.262 \\
\hline 3808 & 380.8 & All & 118.3 & 14.4 & 0.65 & 4.31 & 1.5 & 0.6 & 0.823 & 0.132 & 0.653 & 0.734 & 0.817 & 0.905 & 0.990 \\
\hline \multicolumn{16}{|c|}{$1^{\text {st }}$ and $2^{\text {nd }}$ class roads } \\
\hline 601 & 60.1 & 1 & 81.1 & 14.7 & 0 & 1.9 & 1.5 & 0.28 & 0.692 & 0.122 & 0.546 & 0.608 & 0.691 & 0.761 & 0.853 \\
\hline 2604 & 260.4 & 2 & 76.7 & 16.9 & 1.9 & 3.3 & 2.6 & 0.4 & 0.746 & 0.14 & 0.57 & 0.649 & 0.738 & 0.835 & 0.931 \\
\hline 3468 & 346.8 & 3 & 71.8 & 18.1 & 3.3 & 5 & 4.2 & 0.49 & 0.84 & 0.19 & 0.606 & 0.698 & 0.828 & 0.958 & 1.077 \\
\hline 3375 & 337.5 & 4 & 68.2 & 19.1 & 5 & 10 & 6.2 & 1.02 & 0.928 & 0.238 & 0.644 & 0.749 & 0.91 & 1.074 & 1.237 \\
\hline 98 & 9.8 & 5 & 48.7 & 10.1 & 10 & - & 11 & 0.95 & 0.962 & 0.262 & 0.602 & 0.727 & 1.005 & 1.165 & 1.274 \\
\hline 10150 & 1015 & All & 72.2 & 18.5 & 0.71 & 16.47 & 4.4 & 1.84 & 0.838 & 0.21 & 0.596 & 0.688 & 0.809 & 0.959 & 1.109 \\
\hline
\end{tabular}

Table 5 Percentage of travelled sections in comfort level according to the ISO 2631-1 as a function of IRI road classes for motorways

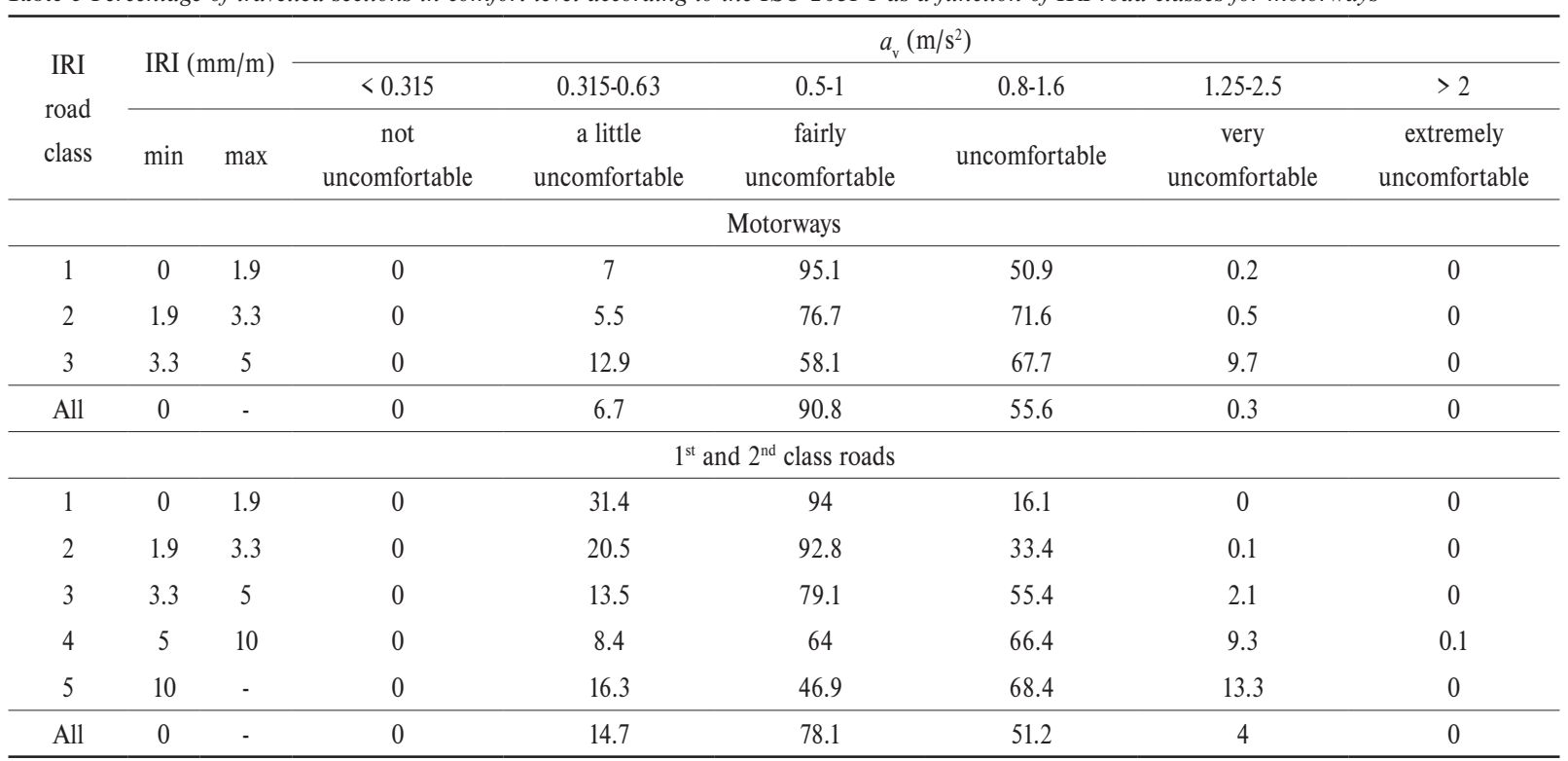

classes $\left(\# 3\right.$ - \#5) for the $1^{\text {st }}$ and $2^{\text {nd }}$ class roads (Table 4). For IRI road class \#3 and motorways and IRI road class \#5 and the $1^{\text {st }}$ and $2^{\text {nd }}$ class roads a lower bound of "very uncomfortable" level $\left(a_{\mathrm{v}}=1.25 \mathrm{~m} / \mathrm{s}^{2}\right)$ was exceeded by the $90^{\text {th }}$ percentile (P90) of $a_{\mathrm{v}}$ (Table 4).

The median values of $a_{\mathrm{v}}$ are shown in Figure 3. Comparison shows higher vibration total value $a_{\mathrm{v}}$ by $17-22 \%$ for motorways in the same IRI road class. Median values of $a_{\mathrm{v}}$ correspond for a "very good" IRI road class \#1 of motorways approximately to "fair" IRI road class \#3 of the $1^{\text {st }}$ and $2^{\text {nd }}$ class roads. The reason may be in much higher typical speeds on motorways and in behaviour of nonlinear characteristics of vehicle suspension elements.

Table 5 and Figure 4 present the percentage of travelled sections in particular comfort levels according to the ISO 2631-1 as a function of the IRI road class and road category. Number of sections, total length of sections and the IRI statistics is the same as in Table 4. Sum of percentage in all six comfort level groups

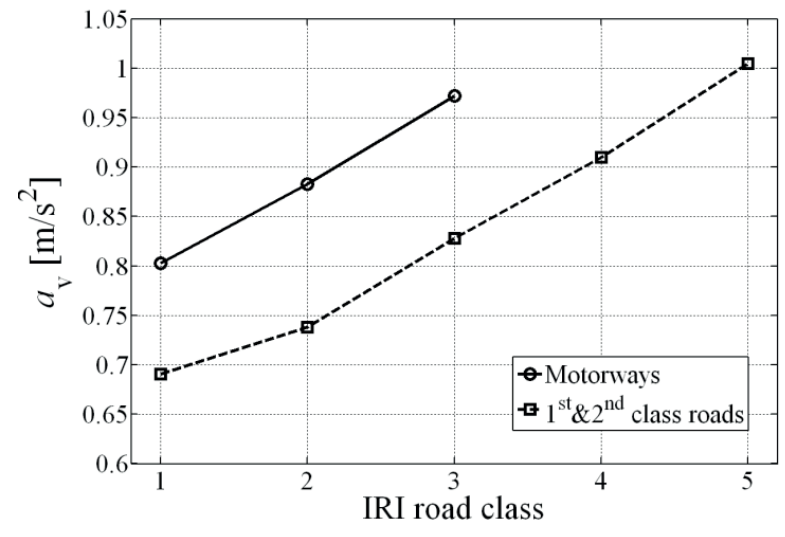

Figure 3 Median of the passenger vibration total value $a_{v}$ as a function of IRI road class and road category 


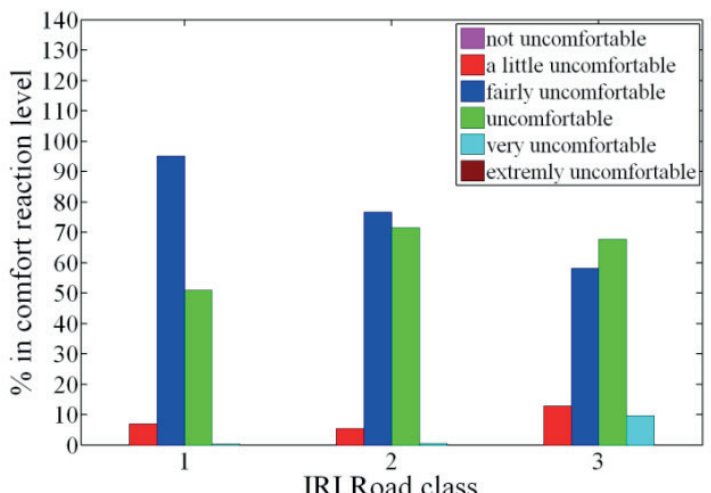

(a)

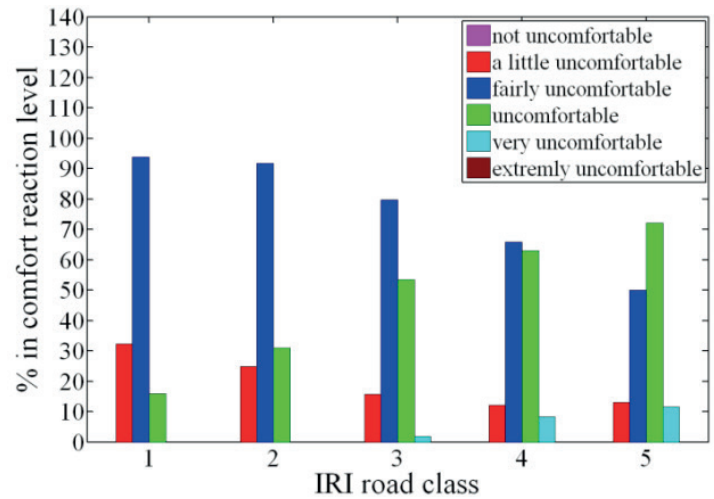

(b)

Figure 4 Percentage of sections in comfort reaction levels according to the ISO 2631-1 as a function of IRI road classes and road category: (a) motorways, (b) the $1^{\text {st }}$ and $2^{\text {nd }}$ class roads

is over $100 \%$ due to overlapped ranges of particular comfort reaction levels groups (Table 1).

On motorways, $55.6 \%$ of processed segments induced passenger's vibrations higher than the lower bound of expected "uncomfortable" human reaction $\left(0.8 \mathrm{~m} / \mathrm{s}^{2}\right)$ and $0.34 \%$ segments exceeded the lower bound of "very uncomfortable" level. On the $1^{\text {st }}$ and $2^{\text {nd }}$ class roads it was $51.4 \%$ ("uncomfortable") and $4 \%$ ("very uncomfortable").

Results in Table 5 may be commented as follows:

- Negligible portion of sections falls in the best and worst comfort likely reaction levels "not uncomfortable" and "extremely uncomfortable".

- Comfort levels "fairly uncomfortable" and "uncomfortable" prevailed.

- Higher percentage (by 12-38\%) of road segments in the same IRI road class corresponds to "fairly uncomfortable" and "uncomfortable" levels for motorways than for the $1^{\text {st }}$ and $2^{\text {nd }}$ class roads. The comparison is influenced with an unequal number of segments $N$ in groups and higher mean speed by 30 to $40 \mathrm{~km} / \mathrm{h}$ on motorways on the section of the same road class.

- Road class \#1 for motorways and road class \#3 for the $1^{\text {st }}$ and $2^{\text {nd }}$ class roads indicate similar percentage of acceleration response in "uncomfortable" category ( $50.9 \%$ vs. $55.4 \%$ ).

- Road class \#3 ("fair") for motorways and road class \#5 ("very poor") for the $1^{\text {st }}$ and $2^{\text {nd }}$ class roads indicate similar percentage of acceleration response in "uncomfortable" category ( $67.7 \%$ vs. $68.4 \%)$.

Results in Tables 4 and 5 suggested that IRI threshold values of particular IRI road classes (Table 1) should be a function of the road speed limit or typical travelled speed of a road category. IRI is proportional to the RMS value of suspension relative velocity [37]. The same level of vibrations response can be achieved for two distinct vehicle speeds with consideration of the same RMS value of suspension relative velocity, $\sigma_{\text {vrel }}\left(v_{1}\right)=\sigma_{\text {vel }}\left(v_{2}\right)$. Then, the relation for the IRI threshold values should be a function of velocity as follows [38]

$$
\operatorname{IRI}\left(v_{2}\right)=\left(\frac{v_{1}}{v_{2}}\right)^{0.5} \operatorname{IRI}\left(v_{1}\right) .
$$

Such a choice of the IRI thresholds should meet the same excited suspension relative velocity response for the two different velocities. It should be stated that relation (3) is valid for Gaussian road profiles and vehicle model with linear suspension characteristics. For example, for two speed limits, $v_{1}=90 \mathrm{~km} / \mathrm{h}$ ( $1^{\text {st }}$ and $2^{\text {nd }}$ class roads) and $v_{2}=130 \mathrm{~km} / \mathrm{h}$ (motorways) it should be hold, IRI $(130 \mathrm{~km} / \mathrm{h})=0.83 \times \operatorname{IRI}(90 \mathrm{~km} / \mathrm{h})$. Thresholds for the critical road state (IRI road class \#5) partially fulfil this assumption. Using Equation (3) to compare IRI thresholds, the correction factor in relation IRI(130) $=f(\operatorname{IRI}(90))$ would be lower at about $0.35-0.5$. Used IRI road classifications around the world used sometimes higher IRI thresholds for partial IRI road classes for roads of lower limit speeds [2].

\section{Conclusions}

A comprehensive overview was provided of the relations between the passenger WBV in a motor vehicle and IRI based on extensive field measurements of a total length of about $1800 \mathrm{~km}$. A summary on this matter has not been previously published in such a wide range.

The novelty of presented results is in estimation of vehicle speed, road category and IRI road class influence on the passenger ride comfort.

The main results of this study were as follows:

1. Parameters of relation between the IRI, passenger vibration total value and vehicle speed were identified as a function of road category. Fitting of measured data suggests that a threeparameter relation is a suitable approximation of this relation.

2. Results specified which combinations of the IRI road class, used in the Slovak Republic, road category and vehicle speed, correspond to particular comfort levels according to the ISO 2631-1.

3. Indication of comfort levels "not uncomfortable" and "extremely uncomfortable" was very rare. Comfort level "fairly uncomfortable" and "uncomfortable" prevailed among comfort categories. About fifty percent of all the processed sections exceeded a lower bound of expected "uncomfortable" reaction $\left(a_{\mathrm{v}}=0.8 \mathrm{~m} / \mathrm{s}^{2}\right)$. About $4 \%$ of processed sections of 
the $1^{\text {st }}$ and $2^{\text {nd }}$ road class exceeded a "very uncomfortable" level.

4. Substantially different passenger's WBV was identified for the same IRI road classes between motorways and the $1^{\text {st }}$ and $2^{\text {nd }}$ class roads. For the same IRI road class, the total passenger vibration was about $20 \%$ higher on motorways. Passenger's WBV for the $i$-th road class of the $1^{\text {st }}$ and $2^{\text {nd }}$ class roads corresponds approximately to the $(i+2)$-th road class of motorways.

5. Experimentally obtained data suggested that the IRI thresholds for partial road classes for motorways should be lower than for the $1^{\text {st }}$ and $2^{\text {nd }}$ class roads to meet approximately the same ride comfort.

\section{Acknowledgements}

This work was supported by the Scientific Grant Agency VEGA of the Ministry of Education, Science, Research and Sport of the Slovak Republic and the Slovak Academy of Sciences [Grant No. 2/0089/16]. Authors would like to thank Dinu Covaciu (Transilvania University of Braşov) and Ing. Stanislav Skyva (Road databank of Slovak Road Administration) for consultations and test drivers Mr. Valentovic and Mr. Rozinaj.

\section{References}

[1] TP 024/2006. Pavement management system (in Slovak). Ministry of Transport, Construction and Regional Development of the Slovak Republic, Bratislava [online], 2006, p. 30. Available from: https://www.ssc.sk/files/documents/technicke-predpisy/tp/ tp_024.pdf

[2] MUCKA, P.: International roughness index specifications around the world. Road Materials and Pavement Design [online]. 2017, 18(4), p. 929-965. ISSN 2164-7402. Available from: https://doi.org/10.1080/14680629.2016.1197144

[3] MERRITT, D. K., CHANG, G. K., RUTLEDGE, J. L. Best practices for achieving and measuring pavement smoothness. A synthesis of state-of-practice. Report No. FHWA/LA.14/550. Austin, TX: TheTranstec Group, Inc., 2015, p. 58.

[4] WANG, F., EASA, S.: Analytical evaluation of ride comfort on asphalt concrete pavements. Journal of Testing Evaluation [online]. 2016, 44(4), p. 1671-1682. ISSN 0090-3973/e-ISSN 1945-7553. Available from: https://doi.org/10.1520/JTE20140339

[5] AHLIN, K., GRANLUND, J., LUNDSTROM, R. Whole-body vibration when riding on rough roads - A shocking study. Rep. 2000:31E. Borlange: Swedish Road Administration, 2002, p. 81. ISSN 1401-9612.

[6] HASSAN, R. A., McMANUS, K. Assessment of interaction between road roughness and heavy vehicles. Transportation Research Record [online]. 2003, 1819, p. 236-243. ISSN 03611981/eISSN 21694052. Available from: https://doi.org/10.3141/1819b-30

[7] IHS, A., GRUDEMO, S., WIKLUND, M. The influence of road surface condition on driving comfort (in Swedish). VTI Report No. 957. Linkoping: Swedish National Road and Transport Research Institute, 2004, p. 131.

[8] FICHERA, G., SCIONTI, M., GARESCI, F. Experimental correlation between the road roughness and the comfort perceived in bus cabins. SAE Technical Paper [online]. 2007, 2007-01-0352. Available from: https://doi.org/10.4271/2007-01-0352

[9] PERERA, R. W., KOHN, S. D., BYRUM, C. R. Smoothness criteria for concrete pavements. Rep. DTFH61-03-C-00105. Washington, DC: Federal Highway Administration, 2009.

[10] WANG, S., ZHANG, J., YANG, Z. Experiment on asphalt pavement roughness evaluation based on passengers' physiological and psychological reaction. In $10^{\text {th }}$ International Conference of Chinese Transportation Professionals (ICCTP) 2010: Integrated Transportation Systems: Green, Intelligent, Reliable : proceedings. H. Wei, Y. Wang, J. Rong, J. Weng, eds. American Society of Civil Engineers, Reston, VA, 2010. ISBN 978-0-7844-1127-8, p. 3852-3863.

[11] ZHANG, J., DU, Y., SU, R. Investigating the relationship between pavement roughness and heart-rate variability by road driving test. In 3rd International Conference on Road Safety and Simulation, Transport Research Board : proceedings [online]. Washington, DC, 2011. Available from: http://onlinepubs.trb.org/onlinepubs/conferences/2011/RSS/2/Zhang,J.pdf

[12] GRANLUND, J. Ride vibration and road condition. In ROADEX IV Final Seminar [online]. The ROADEX Implementing Accessibility Project, The Northern Periphery Programme. Rovaniemi, Finland, 2012 [accessed 2015-05-14]. Available from: http:// www.roadex.org/wp-content/uploads/2014/01/11.-Ride-vibration-and-road-condition-J-Granlund.pdf $>$ (May. 14, 2015).

[13] LEE, D.-H., et al. Study about the evaluation of driving stability using 3-axis accelerometer test. Journal of the Korean Society of Road Engineers. 2012, 14(3), p. 141-149.

[14] HU, J., et al. Research on comfort and safety threshold of the pavement roughness. Report No. 17-02974. Transportation Research Board 96th Annual Meeting. Washington DC, United States: Transportation Research Board, 2017, p. 14.

[15] ZURAULIS, V., PECELIUNAS, R., JAKUTIS, G. Semi-active suspension influence on comfort sensation of a vehicle occupant. Agricultural Engineering [online]. 2014, 46(1), p. 116-124. ISSN 1392-1134/eISSN 2345-0371. Available from: https://doi. org/10.15544/ageng.2014.011

[16] MUCKA, P. Road roughness limit values based on measured vehicle vibration. Journal of Infrastructure Systems [online]. 2017, 23(2), p. 1-13. ISSN 1076-0342/eISSN 1943-555X. Available from: https://doi.org/10.1061/(ASCE)IS.1943-555X.0000325 
[17] SAYERS, M. W. On the calculation of international roughness index from longitudinal road profile. Transportation Research Record [online]. 1995, 1501, 1995, p. 1-12. ISSN 0361-1981/ eISSN 2169-4052. Available from: http://onlinepubs.trb.org/Onlinepubs/ $\operatorname{trr} / 1995 / 1501 / 1501-001 . p d f$

[18] prEN 13036-5. Road and airfield surface characteristics - Test methods. Part 5: Determination of longitudinal unevenness indices. Brussels: European Committee for Standardization (CEN), 2017.

[19] E1926-08. Standard practice for computing International Roughness Index of roads from longitudinal profile measurements. West Conshohocken, PA: ASTM, 2015.

[20] TP 056/2012. Measurement and evaluation of road roughness using Profilograph GE (in Slovak). Ministry of Transport, Construction and Regional Development of the Slovak Republic, Bratislava, SR [online], 2012, p. 20. Available from: https://www.ssc.sk/files/ documents/technicke-predpisy/tp/tp_056.pdf

[21] TP 057/2018. Methodology for using HDM-4 in the conditions of Slovak republic (in Slovak), Ministry of Transport, Construction and Regional Development of the Slovak Republic, Bratislava, SR [online], 2018, p. 79. Available from: https://www.ssc.sk/files/ documents/technicke-predpisy/tp/tp_057.pdf

[22] KOVAC, M., et al. Diagnostic of Parameters of Roads Operational Capability (in Slovak). Zilina: EDIS, University of Zilina, 2012. ISBN 978-80-554-0568-1.

[23] CELKO, J., et al. Pavement diagnosis as integrant of the pavement system. Communications - Scientific Letters of the University of Zilina [online]. 2008, 10(2), p. 44-49. ISSN 1335-4205/eISSN 2585-7878. Available from: http://komunikacie.uniza.sk/index.php/ communications/article/view/1044

[24] CELKO, J., KOVAC, M., DECKY, M. Analysis of selected pavement serviceability parameters. Communications - Scientific Letters of the University of Zilina [online]. 2011, 13(3), p. 56-62. ISSN 1335-4205/eISSN 2585-7878. Available from: http://komunikacie. uniza.sk/index.php/communications/article/view/864

[25] MIKOLAJ, J., REMEK, L., PEPUCHA, L. Overview of the road network management system. Communications - Scientific Letters of the University of Zilina [online]. 2014, 16(4), p. 53-57. ISSN 1335-4205/eISSN 2585-7878. Available from: http://komunikacie. uniza.sk/index.php/communications/article/view/576

[26] DECKY, M., KOVAC, M. The longitudinal road evenness of the road network (in Slovak). Zilina: EDIS, University of Zilina, 2014. ISBN 978-80-554-0925-2.

[27] MUCKA, P.: Porovnanie klasifikacie pozdíznej nerovnosti podla IRI v Slovenskej a Ceskej republike (Comparison of the classification of longitudinal road unevenness according to IRI in the Slovak Republic and the Czech Republic). Silnicni Obzor. 2018, in print. ISSN $0322-7154$.

[28] ISO 2631-1. Mechanical vibration and shock - Evaluation of human response to whole-body vibration. Part I: General requirements. Geneva, Switzerland: International Standardization Organization, 1997.

[29] GRIFFIN, M. J. Discomfort from feeling vehicle vibration. Vehicle Systems Dynamics [online]. 2007, 45(7-8), p. 679-698. ISSN 0042-3114/eISSN 1744-5159. Available from: https://doi.org/10.1080/00423110701422426

[30] STEIN, G. J., CHMURNY, R., ROSIK, V. Compact vibration measuring system for in-vehicle applications. Measurement Science Review [online]. 2011, 11(5), p. 154-159. ISSN 1335-8871. Available from: https://doi.org/10.2478/v10048-011-0030-1

[31] STEIN, G. J., CHMURNY, R., ROSIK, V. Measurement and analysis of low frequency vibration. Measurement Science Review [online]. 2007, 7(4), p. 47-50. ISSN 1335-8871. Available from: http://www.measurement.sk/2007/S3/Stein.pdf

[32] Crossbow CLX Series Datasheet. Crossbow Technology [online]. San Jose, CA [accessed 2018-05-01]. Available from: https://www. willow.co.uk/LP1.pdf

[33] GPS 18x Technical Specifications. Garmin International, Inc. [online]. Olathe, KS, Oct 2011 [accessed 2018-04-30]. Available from: https://static.garmincdn.com/pumac/GPS_18x_Tech_Specs.pdf

[34] COVACIU, D, PREDA, I, CIOLAN, G. GPS based data acquisition system for mobile applications. Acta Technica Jaurinensis [online]. 2011, 4(4), p. 453-464. eISSN 2064-5228. Available from: https://acta.sze.hu/index.php/acta/article/view/265

[35] DT9816 Series User's Manual. Data Translation, Inc. [online]. Locke Drive Marlboro, MA, 2015, p. 108 [accessed 2018-04-30]. Available from: https://datatranslation.box.com/shared/static/9c7ad0d414e6a3f67795.pdf

[36] ASTM E950/E950M-09. Standard test method for measuring the longitudinal profile of traveled surfaces with an accelerometer established inertial profiling reference. West Conshohocken, PA: ASTM International, 2009.

[37] SUN, L., ZHANG, Z., RUTH, J. Modeling indirect statistics of surface roughness. Journal of Transportation Engineering [online]. 2001, 127(2), p. 105-111. ISSN 0733947X. Available from: http://citeseerx.ist.psu.edu/viewdoc/ download?doi=10.1.1.716.4546\&rep=rep1\&type=pdf

[38] MUCKA, P. Influence of profile specification on International Roughness Index. Journal of Infrastructure Systems. 2018, accepted for publication. ISSN 1076-0342/eISSN 1943-555X. 